\title{
Retraction Note: The influence of atmospheric pollutant concentration in basin area and the design of architectural space art form
}

\author{
Pingyu Wang ${ }^{1} \cdot$ Yun Huang ${ }^{1}$
}

Published online: 7 December 2021

C) Saudi Society for Geosciences 2021

Retraction Note: Arabian Journal of Geosciences (2021) 14: 1003

https://doi.org/10.1007/s12517-021-07183-3

The Editor-in-Chief and the Publisher have retracted this article because the content of this article is nonsensical. The peer review process was not carried out in accordance with the Publisher's peer review policy. Author Pingyu Wang has not responded to correspondence regarding this retraction. The Publisher has not been able to obtain a current email address for author Yun Huang.

The online version of the original article can be found at https:// doi.org/10.1007/s12517-021-07183-3

Pingyu Wang

wangpingyu12@163.com

1 Sichuan Fine Arts Institute, Chongqing 400031, China 